\title{
ANALISIS MODAL KERJA DAN LIKUIDITAS UNTUK MENINGKATKAN PROFITABILITAS PADA PT KARYA MURNI PERKASA MEDAN
}

\author{
${ }^{1}$ Ilham Sonata, ${ }^{2}$ Seri Ramadhani \\ Universitas Islam Sumatera Utara \\ sonatailham@gmail.com,sariramadhanii18@icloud.com
}

\begin{abstract}
This study aims to determine working capital turnover and liquidity on profitability in 2018-2019 at PT. Karya Murni Perkasa Medan. The type of data used is secondary data, the data has been processed and obtained from sources that have been documented in the company including financial statements for 2018 and 2016 as well as company history and the data analysis technique used is by using descriptive methods, namely methods using data compiled, interpreted and analyzed so as to provide a clear and complete picture for solving the problems encountered. Based on the financial statements in the form of a statement of financial position and income statement, analyzed using financial ratios. Based on the results of research and discussion, it can be concluded that Working Capital as a whole can be said to be less good, because Working Capital Turnover has decreased from 2018-2019. Liquidity, measured by using the current ratio, quick ratio and cash ratio shows that the company's condition is in good condition, but when compared to the industry average standard, the liquidity ratio in 2018-2019 is declared not good because it is below the average. Financial performance PT. Karya Murni Perkasa in terms of profitability shows the company's financial condition, it is known that net profit margin, return on assets and return on equity have the same ratio level, namely a decrease in each ratio in 20182019 and when compared to the industry average standard, each ratio in 2018-2019 is not good because it is still below the average.
\end{abstract}

Keywords: Working Capital, Liquidity and Profitability

\begin{abstract}
ABSTRAK : Penelitian ini bertujuan untuk mengetahui Perputaran Modal kerja dan Likuiditas terhadap Profitabilitas pada tahun 2018-2019 di PT. Karya Murni Perkasa Medan. Jenis data yang digunakan adalah data sekunder, data tersebut telah diolah dan diperoleh dari sumber yang sudah terdokumentasikan diperusahaan meliputi laporan keuangan untuk tahun 2018 dan 2016 serta sejarah perusahaan dan Teknik Analisis data yang digunakan adalah dengan menggunakan metode deskriptif yaitu metode dengan menggunakan data yang disusun, diinterpretasikan dan dianalisis sehingga memberikan gambaran yang jelas dan lengkap bagi pemecahan masalah yang dihadapi. Berdasarkan laporan keuangan yang berupa Laporan Posisi keuangan dan laporan laba rugi, dianalisi dengan menggunakan rasio-rasio keuangan. Berdasarkan hasil penelitian dan pembahasan dapat disimpulkan bahwa Modal Kerja secara keseluruhan dapat dikatakan kurang baik, karena Perputaran Modal Kerja mengalami penurunan dari tahun 2018-2019. Likuiditas, diukur dengan menggunakan current ratio, quick ratio dan cash ratio menunjukkan bahwa kondisi perusahaan dalam keadaan baik akan tetapi jika dibandingkan dengan standar rata-rata industri maka rasio likuiditas pada tahun 2018-2019 ini dinyatakan tidak baik karena dibawah ratarata.Kinerja keuangan PT. Karya Murni Perkasa ditinjau dari Profitabilitas menunjukan kondisi keuangan perusahaan diketahui bahwa net profit margin, return on assets dan return on equity memiliki tingkat rasio yang sama yakni terjadinya penurunan di setiap rasio nya pada tahun 20182019 dan jika dibandingkan dengan standar rata-rata industri maka tiap rasio pada tahun 20182019 ini tidak baik karena masih dibawah rata-rata.
\end{abstract}

Kata kunci: Modal Kerja, Likuiditas dan Profitabilitas 


\section{Pendahuluan (Introduction)}

Perkembangan teknologi yang saat ini semakin ketat dengan adanya persaingan dalam dunia bisnis. Para investor biasanya memfokuskan pada analisis profitabilitas sebelum melakukan investasi pada suatu perusahaan. Oleh karena itu, perusahaan dituntut harus selalu menjaga kondisi profitabilitasnya agar dapat stabil sehingga investor akan tertarik untuk berinvestasi pada perusahaan tersebut. Dengan profitabilitas yang stabil perusahaan akan dapat menjaga kelangsungan usahanya, sebaliknya apabila perusahaan tidak mampu untuk menghasilkan profitabilitas yang memuaskan maka perusahaan tidak akan mampu menjaga kelangsungan usahanya.

Modal kerja merupakan salah satu faktor yang dapat mempengaruhi bagian lainnya dalam suatu perusahaan. Modal kerja dapat diperoleh baik dari dalam (laba ditahan dan modal sendiri), maupun dari luar (pinjaman). Modal kerja menjadi sumber utama dalam menjalankan suatu usaha, misalnya kekurangan bahan baku akan menghambat proses produksi. Jika hal ini terjadi, maka akan mengakibatkan keterlambatan penyerahan barang sehingga kemungkinan besar pelanggan akan beralih pada menjalankan tugas dan fungsinya sesuai dengan ketentuan produk lain, yang artinya profit atau keuntungan perusahaan akan berkurang. Manajemen modal yang efektif menjadi sangat penting untuk pertumbuhan kelangsungan perusahaan dalam jangka panjang. Apabila perusahaan kekurangan modal kerja untuk memperluas penjualan dan meningkatkan produksinya, maka besar kemungkinannya akan kehilangan pendapatan dan keuntungan. Perusahaan yang tidak memiliki modal kerja yang cukup, tidak dapat membayar kewajiban jangka pendek tepat pada waktunya dan akan menghadapi masalah likuiditas. Modal kerja terkait dengan penyediaan kas, piutang, surat berharga serta persediaan.

Likuiditas adalah salah satu indikator yang digunakan untuk mengukur tinggi atau rendahnya sebuah risiko di perusahaan. Dapat diartikan jika likuiditas di sebuah perusahaan tinggi maka risiko yang ada di perusahaan tersebut rendah, artinya perusahaan akan aman dari kemungkinan kegagalan membayar berbagai kewajiban lancar. Sedangkan untuk likuiditas yang rendah dapat diartikan bahwa risiko yang ada di perusahaan tersebut bisa di bilang tinggi, artinya perusahaan akan mengalami kesulitan atau kegagalan membayar berbagai kewajiban lancar.

Berdasarkan latar belakang beberapa teori, penelitian terdahulu dan fenomena masalah yang ada, maka dilakukan penelitian yang berguna yang bertujuan untuk mengetahui bagaimana Modal dan Likuiditas terhadap peningkatan profitabilitas di perusahaan PT Karya Murni Perkasa Medan baik secara simultan maupun parsial. Hal tersebut yang menjadi latar belakang penulis dalam melakukan penelitian tentang "Analisis modal kerja dan likuiditas untuk meningkatkan profitabilitas PT Karya Murni Perkasa Medan “

\subsection{Identifikasi Masalah}

Berdasarkan latar belakang masalah, maka penulis mengidentifikasi masalah adalah Perusahaan PT. Karya Murni Perkasa Medan menggunakan metode rasio modal kerja, likuiditas dan profitabilitas.

a. Terjadinya penurunan hutang lancar pada rasio modal kerja dan likuiditas tahun 2019 pada PT. Karya Murni Perkasa Medan.

b. Terjadinya penurunan rasio modal kerja pada nilai WCT tahun 2019 pada PT. Karya Murni Perkasa Medan.

c. Terjadinya penurunan persediaan pada rasio likuiditas tahun 2019 pada PT. Karya Murni Perkasa Medan.

d. Terjadinya penurunan persediaan pada rasio likuiditas tahun 2019 pada PT. Karya Murni Perkasa Medan.

\subsection{Rumusan Masalah}

Berdasarkan uraian dan penjelasan dari latar belakang yang telah dikemukakan sebelumnya, maka dirumuskan masalah yang menjadi dasar dalam penyusunan skripsi, yaitu:

a. Bagaimana modal kerja pada PT. Karya Murni Perkasa Medan 2018-2019.

b. Bagaimana likuiditas pada PT. Karya Murni Perkasa Medan 2018-2019.

c. Bagaimana profitabilitas pada PT. Karya Murni Perkasa Medan 2018-2019.

\section{Landasan Teori (Literature Review) \\ 2.1. Modal Kerja}

Menurut Sutrisno (2012:39) menjelaskan pengertian modal kerja sebagai berikut : "Modal kerja adalah dana yang dibutuhkan perusahaan untuk memenuhi kebutuhan 
sehari-hari, seperti pembelian bahan baku, pembayaran upah buruh, membayar hutang, dan pembayaran lainnya".

$$
\mathrm{WCT}=\frac{\text { Penjualan }}{\text { Aktiva lancar-Hutang lancar }}
$$

\subsection{Likuiditas}

Menurut Kasmir (2016:129) menyebutkan bahwa rasio likuiditas merupakan rasio yang menggambarkan kemampuan perusahaan dalam memenuhi kewajiban (hutang) jangka pendek. Artinya apabila perusahaan ditagih, perusahaan akan mampu untuk memenuhi hutang tersebut terutama hutang yang sudah jatuh tempo. Dengan kata lain rasio likuiditas berfungsi untuk menunjukkan atau mengukur kemampuan perusahaan dalam memenuhi kewajibanya yang sudah jatuh tempo baik kewajiban kepada pihak luar perusahaan maupun didalam perusahaan. Dengan demikian, dapat dikatakan bahwa kegunaan rasio ini adalah untuk mengetahui kemampuan perusahaan dalam membiayai dan memenuhi kewajiban (hutang) pada saat ditagih.

a. Current ratio $=\frac{\text { Aktiva Lancar }}{\text { Kewajiban Lancar }} \times 100 \%$

b. Cas Ratio $=\frac{\text { Kas }}{\text { Hutang Lancar }} x 100 \%$

c. Quick Ratio $=\frac{\text { Aktiva Lancar-Persediaan }}{\text { Hutang Lancar }} \times$ $100 \%$

\subsection{Profitabilitas}

Menurut Kasmir (2014:115) definisi rasio profitabilitas merupakan rasio untuk menilai kemampuan perusahaan dalam mencari keuntungan. Rasio ini juga memberikan ukuran tingkat efektivitas manajemen suatu perusahaan. Hal ini ditunjukkan oleh laba yang dihasilkan dari penjualan dan pendapatan investasi. Intinya bahwa penggunaan rasio ini menunjukkan efisiensi perusahaan.
a. $\quad \mathrm{NPM}=\frac{\text { Laba Bersih Setelah Pajak }}{\text { Penjualan Bersih }} \times 100 \%$
b. $\mathrm{ROE}=\frac{\text { Laba Bersih Setelah Pajak }}{\text { Total Modal }} \times 100 \%$
c. $\mathrm{ROA}=\frac{\text { Laba Bersih Setelah Pajak }}{\text { Total Aktiva }} \times 100 \%$

\section{Metode Penelitian (Method/Research Design)}

Adapun Lokasi penelitian adalah tempat dimana peneliti melakukan penelitian yaitu dilakukan pada PT. Karya Murni Perkasa Medan Jalan. Sei Musi No.21-A/15, Medan, Phone : (061) 4157075, 4534621; Fax. (061) 4159319,Medan -20121 e-mail : pt.karya.murni@gmail.com

Jenis data yang digunakan dalam penelitian ini adalah data kuantitatif, dimana data ini berupa laporan keuangan dan gambaran umum perusahaan yang diperoleh dari PT. Karya Murni Perkasa Medan. Dalam penelitian ini menggunakan data sekunder yang diperoleh berupa dokumen laporan keuangan tahun 2018 dan 2019 dari PT. Karya Murni Perkasa Medan.

Teknik pengumpulan data yang digunakan pada penelelitian ini adalah teknik studi dokumentasi. Dalam penelitian ini jenis data yang digunakan peneliti adalah data sekunder yaitu data yang tidak di dapatkan secara langsung dari objek melainkan berupa lampirang laporan keuangan yang diperoleh dari PT. Karya Murni Perkasa Medan terkait laporan keuangan perusahaan.

\section{Hasil Penelitian/Temuan (Findings)}

\section{a. Rasio Modal Kerja}

Menurut Housten (2014:131) Modal kerja dapat diartikan sebagai penjumlahan dari aktiva lancar. Aktiva lancar tersebut merupakan modal kerja kotor. Pengartian ini bersifat kuantitatif sebab jumlah dana yang digunakan dalam tujuan operasi jangka pendek. Ketersediaan modal kerja sangat bergantung pada tingkat likuiditas aktiva lancar seperti kas, surat berharga, persediaan dan piutang.

\section{Standart industri}

\begin{tabular}{|l|l|l|}
\hline No & Keterangan Rasio & Standart Industri \\
\hline & Modal Kerja & 6 Kali \\
\hline 1 & Working Capital Turn Over & Sasmir, (2017:187),2021
\end{tabular}

Berdasarkan rasio yang digunakan pada a. Working Capital Turn Over penelitian ini adalah sebagai berikut: 
$\mathrm{WCT}=\frac{\text { Penjualan }}{\text { Aktiva lancar-Hutang lancar }}$

Tahun $2018=\frac{37.555 .560 .459}{38.751 .122 .439-29.115 .439 .912}$

Tahun $2018=\frac{37.555 .560 .459}{9.635 .682 .527}$

Tahun $2018=4$ Kali

Tahun $2019=\frac{39.340 .046 .784}{46.668 .447 .212-27.259 .007 .941}$

Tahun $2019=\frac{39.340 .046 .784}{19.409 .439 .271}$

Tahun $2019=2$ Kali

\section{b. Rasio Likuiditas}

Menurut Hery (2015:175) menyatakan bahwa rasio likuiditas adalah rasio yang menunjukkan kemampuan perusahaan dalam memenuhi kewajiban atau membayar utang jangka pendeknya. Dengan kata lain, rasio likuiditas adalah rasio yang dapat digunakan untuk mengukur sampai seberapa jauh tingkat kemampuan perusahaan dalam melunasi kewajiban jangka pendeknya yang akan segera jatuh tempo.

\section{Standart industri}

\begin{tabular}{|l|l|c|}
\hline No & Keterangan Rasio & $\begin{array}{l}\text { Standart } \\
\text { Industri }\end{array}$ \\
\hline & Rasio Likuiditas \\
\hline 1 & Current Ratio & $200 \%$ \\
\hline 2 & Quick Ratio & $150 \%$ \\
\hline 3 & Cash Ratio & $50 \%$ \\
\hline
\end{tabular}

Sumber: Kasmir, (2017:187),2021

Berdasarkan rasio yang digunakan pada penelitian ini adalah sebagai berikut:

\section{a. Current Ratio}

Current ratio $=\frac{\text { Aktiva Lancar }}{\text { Kewajiban Lancar }} \times 100 \%$

Tahun $2018=\frac{38.351 .122 .439}{29.115 .439 .912} \times 100 \%$

Tahun $2018=133 \%$

Tahun $2019=\frac{46.668 .447 .212}{27.259 .007 .941} \times 100 \%$

Tahun $2019=171 \%$

b. Quick Ratio
Quick Ratio $=\frac{\text { Aktiva Lancar }- \text { Persediaan }}{\text { Hutang Lancar }} \mathrm{x}$ $100 \%$

Tahun $2018=\frac{38.751 .122 .439-27.283 .507 .478}{29.115 .439 .912} \mathrm{x}$ $100 \%$

Tahun $2018=\frac{11.467 .614 .961}{29.115 .439 .912} \times 100 \%$

Tahun $2018=39,38 \%$

Tahun $2019=\frac{46.668 .447 .212-17.914 .417 .709}{27.259 .007 .941} \times$ $100 \%$

Tahun $2019=\frac{28.754 .029 .503}{27.259 .007 .941} \times 100 \%$

Tahun $2019=105,4 \%$

c. Cash Ratio

Cash Ratio $=\frac{\text { Kas }}{\text { Hutang Lancar }} \times 100 \%$

Tahun $2018=\frac{791.847 .881}{29.115 .439 .912} \times 100 \%$

Tahun $2018=2,71 \%$

Tahun $2019=\frac{766.427 .935}{27.259 .007 .941} \times 100 \%$

Tahun $2019=2,81 \%$

\section{c. Rasio Profitabilitas}

Menurut Kasmir (2014:115) definisi rasio profitabilitas merupakan rasio untuk menilai kemampuan perusahaan dalam mencari keuntungan. Rasio ini juga memberikan ukuran tingkat efektivitas manajemen suatu perusahaan. Hal ini ditunjukkan oleh laba yang dihasilkan dari penjualan dan pendapatan investasi. Intinya bahwa penggunaan rasio ini menunjukkan efisiensi perusahaan.

\begin{tabular}{|l|l|r|}
\multicolumn{3}{|c}{ Standart industri } \\
\hline No & Keterangan Rasio & $\begin{array}{l}\text { Standart } \\
\text { Industri }\end{array}$ \\
\hline & \multicolumn{2}{|l|}{ Rasio Profitabilitas } \\
\hline 1 & Return On Assets & $30 \%$ \\
\hline 2 & Return On Equity & $40 \%$ \\
\hline 3 & Net Profit Margin & $20 \%$ \\
\hline
\end{tabular}

Sumber: Kasmir, (2017:187),2021

Berdasarkan rasio yang digunakan pada penelitian ini adalah sebagi berikut: 
a. Return On Assets

ROA $=\frac{\text { Laba Bersih Setelah Pajak }}{\text { Total Aktiva }} \times 100 \%$

Tahun $2018=\frac{1.277 .927 .273}{50.152 .755 .435} \times 100 \%$

Tahun $2018=2,54 \%$

Tahun $2019=\frac{463.767 .838}{59.415 .627 .303} \times 100 \%$

Tahun $2019=0,78 \%$

\section{b. Return On Equity}

$\mathrm{ROE}=\frac{\text { Laba Bersih Setelah Pajak }}{\text { Total Modal }} \times 100 \%$

Tahun $2018=\frac{1.277 .927 .273}{20.078 .617 .524} \times 100 \%$

Tahun $2018=6,36 \%$

Tahun $2019=\frac{463.767 .838}{31.175 .635 .863} \times 100 \%$

Tahun $2019=1,48 \%$

c. Net Profit Margin

$\mathrm{NPM}=\frac{\text { Laba Bersih Setelah Pajak }}{\text { Penjualan Bersih }}$ X 100\%

Tahun $2018=\frac{1.277 .927 .273}{37.555 .560 .459} \times 100 \%$

Tahun $2018=3,40 \%$

Tahun $2019=\frac{463.767 .838}{39.340 .046 .786} \times 100 \%$

Tahun $2019=1,17 \%$

\section{Kesimpulan}

Berdasarkan hasil analisis data penelitian dengan menggunakan analisis rasio terhadap laporan keuangan tahun 2018-2019 pada PT. Karya Murni Perkasa Medan dapat dibuat kesimpulan penelitian sebagai berikut:

a. Kinerja keuangan PT. Karya Murni Perkasa ditinjau dari Modal kerja secara keseluruhan dapat dikatakan kurang baik, karena perputaran modal kerja mengalami penurunan dari tahun 2018 ke 2019 dan jika dibandingkan dengan standar rata-rata industri maka rasio modal kerja tahun 20182019 ini tidak baik karena masih dibawah rata-rata. b. Kinerja keuangan PT. Karya Murni Perkasa ditinjau dari Likuiditas menunjukkan kondisi keuangan perusahaan diketahui bahwa Current Ratio,Quick Ratio dan Cash Ratio memiliki tingkat rasio yang sama yakni terjadinya penaikan di setiap rasio nya pada tahun 2018-2019. Hal ini disebabkan karena aktiva lancar mengalami kenaikan dari tahun 2018 ke 2019 akan tetapi jika dibandingkan dengan standar rata-rata industri maka tiap rasio pada tahun 20182019 ini tidak baik karena masih dibawah rata-rata.

c. Kinerja keuangan PT. Karya Murni Perkasa ditinjau dari Profitabilitas menunjukkan kondisi keuangan perusahaan diketahui bahwa Net Profit Margin ,Return on Assets dan Return on Equity memiliki tingkat rasio yang sama yakni terjadinya penurunan di setiap rasio nya pada tahun 2018-2019 dan jika dibandingkan dengan standar rata-rata industri maka.

\section{DAFTAR PUSTAKA}

Aripin (2015). Pengelolaan Modal Kerja Terhadap Profitabilitas Perusahaan Food And Beverage. Palembang

Bambang Riyanto. (2011). Dasar-dasar Pembelanjaan Perusahaan. Yogyakarta:BPFE.

Bambang, Riyanto. (2012). Dasar-dasar Pembelanjaan, Edisi 4, Yogyakarta: BPFE

Brigham, E. F \& Houston, J. F. (2014). Dasardasar Manajemen Keuangan. Jakarta:Erlangga.

Harahap Sofyan (2015).Analisis Kritis Atas Laporan Keuangan.Jakarta : PT Rajagrafindo Persada.

Hery.(2015). AnalisisLaporan Keuangan.

Edisi 1. Yogyakarta :Center For AcademicPublishing Services.

I Made Sudana, Manajemen (2011) Keuangan Perusahaan Teori dan Praktik,Jakarta: Erlangga.

Kasmir.(2008). Analisis Laporan Keuangan. Jakarta: PT RajaGrafindo Persada.

Kasmir.(2012), Analisis Laporan Keuangan. Jakarta : PT. Raja GrafindoPersada

Kasmir, (2014). Analisis Laporan Keuangan, Edisi Pertama, Cetakan Ketujuh. Jakarta: PT. Rajagrafindo Persada.

Kasmir. (2015). Analisis Laporan Keuangan. Jakarta : PT Raja Grafindo Persada. 
Kasmir, (2016). Analisis Laporan Keuangan. Jakarta: Raja Grafindo Persada.

Kasmir. (2017). Analisis Laporan Keuangan. Jakarta: PT Rajagrafindo Persada.

Kasmir. (2018). Analisis Laporan Keuangan. Jakarta: PT. Raja Grafindo Persada.

Munawir, S.(2012). Analisa Laporan Keuangan. Yogyakarta: Liberty.

Munawir. (2014). Analisis Laporan Keuangan. Yogyakarta : Liberty.

Poppy Rufaidah. (2014). Manajemen Strategik. Cetakan Ketiga. Bandung : Humaniora.

Sugiyono. (2014). Metode Penelitian Pendidikan Pendekatan Kuantitatif, Kualitatif, dan $\quad R \& D . \quad$ Bandung: Alfabeta.

Sutrisno. (2012).Manajemen Keuangan Teori, Konsep dan Aplikasi.Yogyakarta: EKONISIA.

Weygandt, and Terry D.Warfield.(2007).Akuntansi Intermediate. Edisi Kedua belas, Jakarta Erlangga. 